\title{
The Critical Aggregation Concentration of $\beta$-Lactoglobulin-Based Fibril Formation
}

\author{
Ardy Kroes-Nijboer • Paul Venema • Jacob Bouman • \\ Erik van der Linden
}

Received: 1 August 2008 /Accepted: 14 January 2009/Published online: 27 January 2009

(C) The Author(s) 2009. This article is published with open access at Springerlink.com

\begin{abstract}
The critical aggregation concentration (CAC) for fibril formation of $\beta$-lactoglobulin $(\beta-\lg )$ at $\mathrm{pH} 2$ was determined at $343,353,358,363$, and $383 \mathrm{~K}$ using a Thioflavin $\mathrm{T}$ assay and was approximately $0.16 \mathrm{wt} \%$. The accuracy of the CAC was increased by measuring the conversion into fibrils at different stirring speeds. The corresponding binding energy per mol, as determined from the $\mathrm{CAC}$, was $13 \mathrm{RT}\left(\sim 40 \mathrm{~kJ} \mathrm{~mol}^{-1}\right)$ for the measured temperature range. The fact that the $\mathrm{CAC}$ was independent of temperature within the experimental error indicates that the fibril formation of $\beta-\lg$ at $\mathrm{pH} 2$ and the measured temperature range is an entropy-driven process.
\end{abstract}

Keywords Protein fibrils $\cdot \beta$-Lactoglobulin $(\beta-\lg ) \cdot$ Critical aggregation concentration $(\mathrm{CAC}) \cdot$ Binding energy $\cdot$ Entropy

\section{Introduction}

Amyloid fibrils are linear protein aggregates that are typically micrometers long but only a few nanometers thick. They can be formed from various food proteins like egg white proteins ${ }^{1-5}$, soy proteins ${ }^{6}$, and whey proteins ${ }^{7-25}$. The fibrils can, for example, be used as structurants and thickeners to give food products a specific texture. However, fibrillar protein aggregation is not only studied because of its potential use in food products, but the

\footnotetext{
A. Kroes-Nijboer $(\bowtie) \cdot$ P. Venema $\cdot$ J. Bouman •

E. van der Linden

Laboratory of Physics and Physical Chemistry of Foods,

Department of Agrotechnology and Food Sciences, Wageningen

University,

Bomenweg 2,

6703 HD Wageningen, The Netherlands

e-mail: ardy.nijboer@wur.nl
}

formation of fibrils is also related with amyloid diseases, where the amyloid fibrils occur in proteinaceous deposits called plaques ${ }^{26}$. Although the amyloid fibrils have been studied in different research areas, there is a common interest in knowledge about the formation and molecular structure of the fibrils. The formation of amyloid fibrils is suggested to be a generic form of aggregation ${ }^{26,27}$. The amyloid fibrils are characterized by a cross- $\beta$ structure ${ }^{28,29}$, where the $\beta$ sheets are arranged parallel to the long axis of the fibril, with their constituent $\beta$-strands perpendicular to this axis ${ }^{30}, 31$. Another property of the amyloid fibrils is that they have the ability to bind to amyloid specific dyes like Congo $\operatorname{Red}^{32}$ and Thioflavin $\mathrm{T}(\mathrm{ThT})^{33}$.

We are interested in the formation of fibrils of $\beta$ lactoglobulin $(\beta-\lg )$, a globular protein that has a molar mass of $18,400 \mathrm{~g} \mathrm{~mol}^{-1}$ and a radius of about $2 \mathrm{~nm}^{11}$. $\beta-\lg$ has been extensively studied because it is readily available in large quantities and because of its importance to the food industry ${ }^{34}$. Fibrils are formed when $\beta-\lg$ is heated at low $\mathrm{pH}$, far from the isoelectric point of the protein $^{11,14,20,24,34,35}$. Despite extensive studies on fibril formation and the fact that it is known how to produce the $\beta-\lg$ fibrils, the fibril formation process is still not completely understood. For instance, the critical aggregation concentration (CAC), which is an important parameter that can be used to estimate binding energies involved in the fibril formation, is still under discussion. Having reliable values for the CAC will lead to a better understanding of the fibril formation process. Values for the CAC of fibril formation of $\beta-\lg$ at $\mathrm{pH} 2$ that are reported in literature show a large disparity. Arnaudov et al. ${ }^{21}$ defined the critical concentration as the concentration where the conversion of protein into fibrils was too low to be determined with nuclear magnetic resonance spectroscopy; in this case, $2.5 \mathrm{wt} \%$ was reported. However, in their 
atomic force microscopy pictures, fibrils were observed in solutions with protein concentrations of $1 \mathrm{wt} \% \quad \beta-\lg ^{21}$. Rogers et al. $^{23}$ found fibril formation in equivalent $\beta$-lg solutions with concentrations as low as $0.5 \mathrm{wt} \%$. In whey protein isolate (WPI) solutions, where $65 \%$ of the protein is $\beta-\mathrm{lg}$, fibrils were formed at concentrations of $0.5 \mathrm{wt} \%$ $\mathrm{WPI}^{24}$. This corresponds to a $\beta-\mathrm{lg}$ concentration of about $0.33 \mathrm{wt} \%$. In short, in literature, the values for the CAC of fibril formation of $\beta-\lg$ at $\mathrm{pH} 2$ range from protein concentrations as low as $0.33 \mathrm{wt} \%$ up to concentrations of $2.5 \mathrm{wt} \%$.

In the present study, an alternative route is used to determine the CAC for fibril formation of $\beta-\lg$ at $\mathrm{pH} 2$ and elevated temperatures, i.e., by using the assumption that flow will influence the kinetics of fibril formation but not the thermodynamics. To obtain CAC values for the fibril formation, the conversion of protein into fibrils as a function of total protein concentration $(0.2-2 \mathrm{wt} \%)$ was measured. This was done using a ThT assay, which is widely used to determine the presence of amyloid fibrils and to examine the kinetics of fibril formation ${ }^{33}$, $34,36-39$. To increase the accuracy of the determination of the CAC, fibrils were produced under different stirring conditions (at rest, stirred at $290 \mathrm{rpm}$, and at 1,200 rpm). The fibril formation starts with reversible aggregation, and upon longer heating, the binding between the building blocks of the fibrils becomes irreversible ${ }^{21,25}$. Therefore, the $\mathrm{CAC}$ at the start of the aggregation process is treated as a thermodynamic equilibrium, and the thermodynamic principles of self-assembly ${ }^{40}$ were used to estimate the corresponding binding energy. The temperature dependence of the CAC was used to estimate the enthalpy and entropy contribution to the fibril formation.

\section{Materials and Methods}

\section{Sample Preparation}

$\beta$-lg was obtained from Sigma (product no. L0130, lot. no. 095K7006). A stock solution (about $9 \mathrm{wt} \%$ ) was made by dissolving the protein powder in $\mathrm{HCl}$ solution of $\mathrm{pH} 2$. The $\mathrm{pH}$ of the protein solution was adjusted to $\mathrm{pH} 2$ with $6 \mathrm{M}$ $\mathrm{HCl}$ solution. Subsequently, this stock solution was filtered through a protein filter (FD 30/0.45 $\mu \mathrm{m}$ Ca-S from Schleicher \& Schuell) to remove any traces of undissolved protein. The protein concentration of the stock solution was determined using a UV spectrophotometer (Cary 50 Bio, Varian) and a calibration curve of known $\beta$-lg concentrations at a wavelength of $278 \mathrm{~nm}$. The stock solution was diluted to protein concentrations of $2,1,0.5$, and $0.2 \mathrm{wt} \%$ with $\mathrm{HCl}$ solution of $\mathrm{pH} 2$.
Heating and Stirring

$\beta-\lg$ solutions of the various protein concentrations were heated in small glass vials $(20 \mathrm{ml})$ in a metal stirring and heating plate for $24 \mathrm{~h}$ at $343,353,358,363$, and $383 \mathrm{~K}$. The protein solutions were stirred during heating at two different stirring rates, corresponding to 290 and 1,200 rpm. At $353 \mathrm{~K}$, a series of protein solutions was also heated at rest. All samples were heated in duplicates. The samples at $383 \mathrm{~K}$ were heated in glass vials $(10 \mathrm{ml})$ with a crimp cap (with septum of silicone/polytetrafluoroethylene $3 \mathrm{~mm}$ ) to allow pressures above atmospheric pressure.

\section{Thioflavin T Fluorescence}

The ThT fluorescence assay was used to measure the conversion of protein into fibrils after heating the protein solutions. A ThT stock solution $(3.0 \mathrm{mM})$ was made by dissolving $7.9 \mathrm{mg}$ ThT in $8 \mathrm{ml}$ phosphate buffer $(10 \mathrm{mM}$ phosphate, $150 \mathrm{mM} \mathrm{NaCl}$ at $\mathrm{pH}$ 7.0). This stock solution was filtered through a $0.2-\mu \mathrm{m}$ filter (Schleicher \& Schuell). The stock solution was diluted 50 times in a phosphate buffer (10 $\mathrm{mM}$ phosphate, $150 \mathrm{mM} \mathrm{NaCl}$ at $\mathrm{pH}$ 7.0) before use.

After heating the protein solutions, aliquots of the fibril samples $(48 \mu \mathrm{l})$ were mixed with $4 \mathrm{ml} \mathrm{ThT}$ solution and allowed to bind to the ThT for $1 \mathrm{~min}$. The fluorescence of the samples was measured using a fluorescence spectrophotometer (Perkin Elmer LS 50 B). The excitation wavelength was set on $460 \mathrm{~nm}$ (slit width $4.0 \mathrm{~nm}$ ), and the emission spectrum was recorded between 470 and $500 \mathrm{~nm}$ (slit width $2.5 \mathrm{~nm}$ ) at a scanning speed of $200 \mathrm{~nm} /$ $\min$. The fluorescence intensity was determined at $482 \mathrm{~nm}$. The fluorescence intensity of the ThT solution was subtracted as a background. The errors in fluorescence were typically $<3 \%$.

\section{Results and Discussion}

\section{$\mathrm{CAC}$ and Stirring}

The fibril formation of $\beta$-lg at $\mathrm{pH} 2$ was strongly dependent on the heating temperature, as can be seen in Figure 1. The optimal temperature for this fibril formation process, i.e., the temperature where the conversion was maximal, was close to $353 \mathrm{~K}$. A similar optimum was found for $0.5 \mathrm{wt} \%$ $\beta-\lg$ under stirred conditions by Rogers et al. ${ }^{41}$.

To determine the CAC for fibril formation at $353 \mathrm{~K}$, the conversion of protein into fibrils was measured as a function of the total protein concentration using a ThT assay. From this, the CAC was determined by extrapolating the conversion data to zero conversion. Figure 2 shows that the conversion of protein into fibrils is linearly 


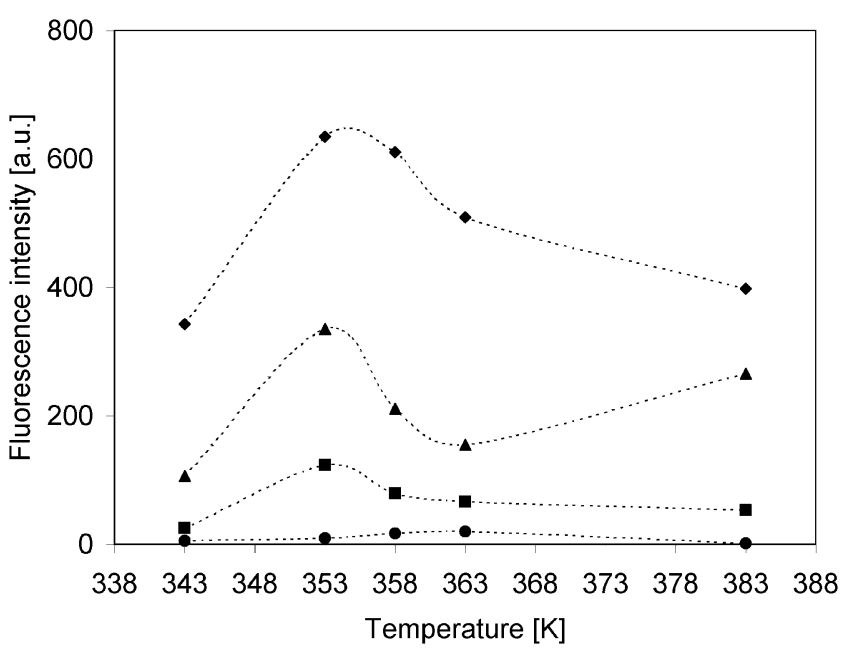

Fig. 1 Maximal conversion of protein into fibrils as a function of temperature for various $\beta$-lg concentrations. Samples were stirred during heating at $290 \mathrm{rpm}$. Closed circles $0.2 \mathrm{wt} \%$, closed squares $0.5 \mathrm{wt} \%$, closed triangles $1 \mathrm{wt} \%$, closed diamonds $2 \mathrm{wt} \%$

related to the total protein concentration, with a slope depending on the stirring rate. The influence of flow on the conversion was also reported by other researchers ${ }^{25,} 42$, ${ }^{43}$. Figure 2 shows that the three lines have a common intersection point at $0.16 \mathrm{wt} \%$, showing that the $\mathrm{CAC}$ for fibril formation is not dependent on the stirring rate. Reversely, the CAC can be determined accurately if one uses different flow conditions. Indeed, the kinetics is changed by the flow (i.e., slope of the lines in Figure 2); the thermodynamics (intersection point of the lines in Figure 2) is not.

\section{Binding Energy}

The thermodynamics of self-assembly was used to estimate the binding energy, i.e., the decrease in the Gibbs free energy when a fibril is extended by $1 \mathrm{~mol}$ of building blocks ${ }^{40}$. For determining the CAC, we do not have to use thermodynamic equilibrium properties. However, at the concentration just below the CAC, thermodynamic equilibrium exists, and the principles of self-assembly are still valid. The relation between the molar fraction of fibrillar (i.e., linear) aggregates consisting of $N$ building blocks, $x_{N}$, and the binding energy, $\alpha$, is given by ${ }^{40}$

$x_{N}=N\left[x_{1} \times e^{\alpha}\right]^{N}$

with $\alpha$ expressed in units of RT and where $x_{1}$ is the molar fraction of the building blocks. From Eq. 1, it follows that for large $N$ and for $x_{1}$ becoming larger than $e^{-\alpha}$, the righthand term becomes much larger than unity, invalidating the requirement that $x_{N}$ should be smaller than 1 . This implies that $x_{1, \mathrm{CAC}} \approx e^{-\alpha}$ is a natural limit of the molar fraction of building blocks and denotes the CAC. Above this concen- tration, aggregates will be formed. The relation between the $\mathrm{CAC}$ and $\alpha$ can thus be written as

$x_{1, \mathrm{CAC}} \approx e^{-\alpha}$

At the optimal temperature for fibril formation $(353 \mathrm{~K})$, the $\mathrm{CAC}$, as determined from Figure 1 at a protein concentration of $0.16 \mathrm{wt} \%\left(x_{1, \mathrm{CAC}}=1.6 \times 10^{-6}\right)$, leads to a binding energy of $13.4 \mathrm{RT}\left(39.1 \mathrm{~kJ} \mathrm{~mol}^{-1}\right)$. Since the fibril formation of $\beta-\lg$ is a complex process where several mechanisms are involved, one should keep in mind that the determined binding energy is the binding energy when the fibrils are extended by $1 \mathrm{~mol}$ of building blocks. After this initial binding, subsequently intermolecular $\beta$-sheet formation will take place ${ }^{14}, 15$, which will make the binding stronger and irreversible, unless a strong chaotropic agent like guanidinium chloride is added ${ }^{21,25,44}$.

\section{Temperature Dependence of the CAC}

To see the effect of temperature on the CAC and binding energy of the fibril formation, the same experiments were also performed at $343,358,363$, and $383 \mathrm{~K}$. For these temperatures, the maximal conversion of protein into fibrils as a function of the total protein concentration are shown in Figure $3 \mathrm{a}-\mathrm{d}$. In order to measure the $\mathrm{CAC}$, we need to determine the protein concentration were the fluorescence signal becomes zero (the CAC). This was done by extrapolating the conversion data to zero conversion. A priori the functional form of the conversion relative to protein concentration is unknown. However, based on the results at $353 \mathrm{~K}$, we have assumed a linear relation between the total protein concentration and the conversion of protein into fibrils at all temperatures. All linear fits gave a $R^{2}>$ 0.94. The CACs and corresponding binding energies for all

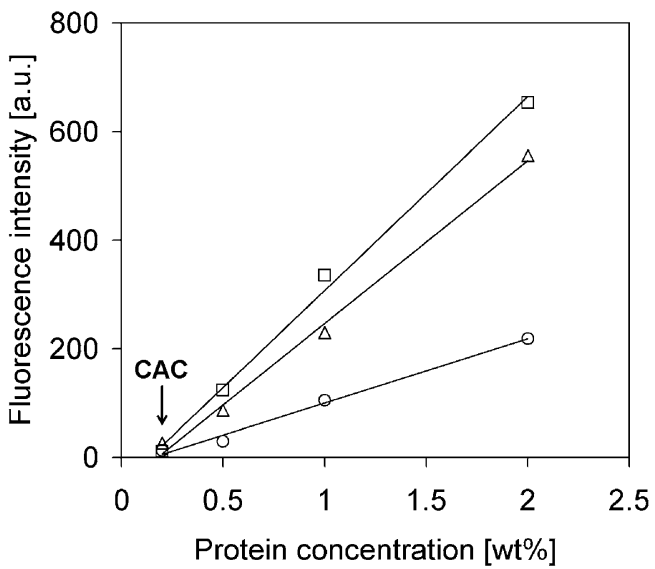

Fig. 2 The protein concentration versus the conversion into fibrils of $\beta$-lg solutions ( $\mathrm{pH} 2$ ) heated for $24 \mathrm{~h}$ at $353 \mathrm{~K}$. The solutions were stirred at $290 \mathrm{rpm}$ (open squares) during heating, stirred at 1,200 rpm (open triangles) during heating or heated in rest (open circles) 
Fig. 3 The protein concentration versus the conversion into fibrils of $\beta$-lg solutions ( $\mathrm{pH} 2$ ) heated at $343 \mathrm{~K}(\mathbf{a}), 358 \mathrm{~K}(\mathbf{b})$, $363 \mathrm{~K}(\mathbf{c})$, and $383 \mathrm{~K}(\mathbf{d})$. The solutions were stirred at $290 \mathrm{rpm}$ (open squares) or stirred at 1,200 rpm (open triangles) during heating
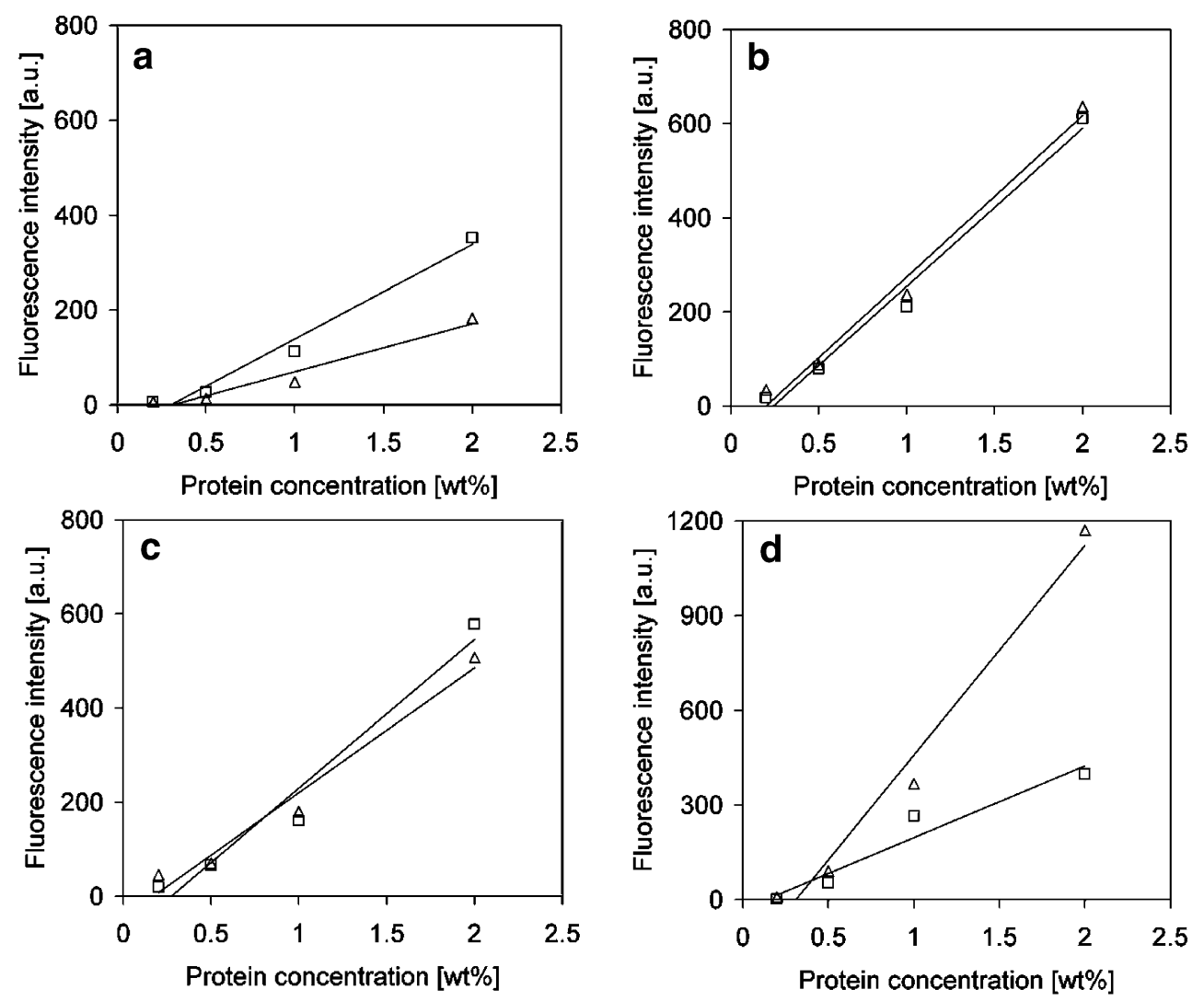

temperatures are shown in Table 1. All the calculated binding energies in Table 1 have a value of about 13 RT (about $40 \mathrm{~kJ} \mathrm{~mol}^{-1}$ ), where the binding energy has a shallow maximum at the temperature where the fibril formation is maximal, $353 \mathrm{~K}$.

Enthalpy and Entropy

Using de Van 't Hoff equation and the temperature dependence of the CAC, the entropy and enthalpy of aggregate formation can be determined (see for example, $\mathrm{Yu}$ et $\mathrm{al}^{45}$ ). For this, the following equations were used:

$\Delta G^{0}=R T \ln x_{1, \mathrm{CAC}}$

Table 1 The CAC and corresponding binding energy $(\alpha)$ at various temperatures

\begin{tabular}{llccc}
\hline $\begin{array}{l}\text { Temperature } \\
(\mathrm{K})\end{array}$ & $\begin{array}{l}\mathrm{CAC} \\
(\mathrm{wt} \%)\end{array}$ & $\begin{array}{l}x_{1, \mathrm{CAC}} \\
(\mathrm{mol} \text { fraction })\end{array}$ & $\alpha(\mathrm{RT})$ & $\alpha\left(\mathrm{kJ} \mathrm{mol}^{-1}\right)$ \\
\hline 343 & 0.33 & $3.2 \mathrm{E}-06$ & 12.6 & 36.1 \\
353 & 0.16 & $1.6 \mathrm{E}-06$ & 13.4 & 39.1 \\
358 & 0.23 & $2.3 \mathrm{E}-06$ & 13.0 & 38.7 \\
363 & 0.24 & $2.4 \mathrm{E}-06$ & 12.9 & 39.1 \\
383 & 0.25 & $2.5 \mathrm{E}-06$ & 12.9 & 41.1 \\
\hline
\end{tabular}

$\Delta H^{0}=-R T^{2}\left[\frac{\partial \ln x_{1, \mathrm{CAC}}}{\partial T}\right]$

$\Delta G^{0}=\Delta H^{0}-T \Delta S^{0}$

where $\Delta G^{0}$ and $\Delta H^{0}$ are standard molar Gibbs free energy and molar enthalpy of aggregate formation and $x_{1, \mathrm{CAC}}$ is the molar fraction of the CAC. With $\Delta G^{0}$ and $\Delta H^{0}$, the molar entropy of aggregate formation, $\Delta S^{0}$ can be obtained. However, the values for the $x_{1, \mathrm{CAC}}$ of fibril formation of $\beta$ $\lg$ at $\mathrm{pH} 2$ do not depend on the temperature (see Table 1) within the experimental error. This means that $\Delta H^{0}$ is close to zero, and as a result, we find that $\Delta S^{0} \cong-\frac{\Delta G^{0}}{T}$. Since $\Delta G^{0}$ is in the order of $-40 \mathrm{~kJ} \mathrm{~mol}^{-1}$ (see Table 1) the change in entropy is positive, making the fibril formation an entropy-driven process.

\section{Conclusion}

The relations between the protein concentration and the conversion into fibrils were extrapolated to obtain the CAC for fibril formation of $\beta-\lg$ at $\mathrm{pH} 2$ and elevated temperatures. The fibril formation took place under different stirring speeds, and although the kinetics of the fibril formation was 
influenced by the stirring speed, the CAC was not. This was used to increase the accuracy at which the CAC was determined. The corresponding binding energy was 13 RT $\left(\sim 40 \mathrm{~kJ} \mathrm{~mol}^{-1}\right)$ for all measured temperatures. This temperature independence indicates that the growth of fibrils obtained from $\beta$-lg is an entropy-driven process.

Acknowledgments The authors acknowledge the Dutch research school VLAG and the Dutch research program MicroNed for the financial support of this project.

Open Access This article is distributed under the terms of the Creative Commons Attribution Noncommercial License which permits any noncommercial use, distribution, and reproduction in any medium, provided the original author(s) and source are credited.

\section{References}

1. M.R.H. Krebs, D.K. Wilkins, E.W. Chung et al., J. Mol. Biol. 300 (3), 541 (2000). doi:10.1006/jmbi.2000.3862

2. C. Veerman, G. de Schiffart, L.M.C. Sagis, E. van der Linden, Int. J. Biol. Macromol. 33(1-3), 121-127 (2003). doi:10.1016/ S0141-8130(03)00076-X

3. L.N. Arnaudov, R. de Vries, Biophys. J. 88(1), 515-526 (2005). doi:10.1529/biophysj.104.048819

4. M. Weijers, L.M.C. Sagis, C. Veerman, B. Sperber, E. van der Linden, Food Hydrocoll. 16(3), 269-276 (2002). doi:10.1016/ S0268-005X(01)00097-2

5. C. Veerman, L.M.C. Sagis, J. Heck, E. van der Linden, Int. J. Biol. Macromol. 31, 139 (2003). doi:10.1016/S0141-8130(02) 00074-0

6. C. Akkermans, A.J. van der Goot, P. Venema et al., J. Agric. Food Chem. 55(24), 9877-9882 (2007). doi:10.1021/jf0718897

7. M. Langton, A.-M. Hermansson, Food Hydrocoll. 5, 523-539 (1992)

8. J.C. Gimel, D. Durand, T. Nicolai, Macromolecules. 27(2), 583 (1994). doi:10.1021/ma00080a037

9. P. Aymard, D. Durand, T. Nicolai, Int. J. Pol. Anal. Char. 2(2), 115-119 (1996). doi:10.1080/10236669608233901

10. D. Renard, J. Lefebvre, M.C.A. Griffin, W.G. Griffin, Int. J. Biol. Macromol. 22(1), 41-49 (1998). doi:10.1016/S0141-8130(97) 00086-X

11. P. Aymard, T. Nicolai, D. Durand, Macromolecules. 32, 25422552 (1999). doi:10.1021/ma981689j

12. C. Le Bon, T. Nicolai, D. Durand, Int. J. Food Sci. Technol. 34 (5-6), 451 (1999). doi:10.1046/j.1365-2621.1999.00310.x

13. W.S. Gosal, S.B. Ross-Murphy, Curr Opin Colloid Interface Sci. 5 (3-4), 188 (2000). doi:10.1016/S1359-0294(00)00057-1

14. G.M. Kavanagh, A.H. Clark, S.B. Ross-Murphy, Int. J. Biol. Macromol. 28, 41-50 (2000). doi:10.1016/S0141-8130(00)00144-6

15. T. Lefèvre, M. Subirade, Biopolymers. 54(7), 578-586 (2000). doi:10.1002/1097-0282(200012)54:7<578::AID-BIP100>3.0.CO;2-2

16. E.P. Schokker, H. Singh, D.N. Pinder, L.K. Creamer, Int. Dairy J. 10(4), 233 (2000). doi:10.1016/S0958-6946(00)00047-9

17. D. Durand, J.C. Gimel, T. Nicolai, Physica A 304(1-2), 253-265 (2002). doi:10.1016/S0378-4371(01)00514-3
18. S. Ikeda, V.J. Morris, Biomacromolecules. 3(2), 382-389 (2002). doi:10.1021/bm0156429

19. W.S. Gosal, A.H. Clark, P.D.A. Pudney, S.B. Ross-Murphy, Langmuir 18, 7174-7181 (2002). doi:10.1021/la025531a

20. C. Veerman, H. Ruis, L.M.C. Sagis, E. van der Linden, Biomacromolecules 3(4), 869 (2002). doi:10.1021/bm025533+

21. L.N. Arnoudov, R. de Vries, H. Ippel, C.P.M. van Mierlo, Biomacromolecules. 4, 1614-1622 (2003). doi:10.1021/ bm034096b

22. C. Veerman, L.M.C. Sagis, E. van der Linden, Macromol. Biosci. 3(5), 243 (2003). doi:10.1002/mabi.200390035

23. S.S. Rogers, P. Venema, L.M.C. Sagis, E. van der Linden, A.M. Donald, Macromolecules 38, 2948-2958 (2005). doi:10.1021/ ma0474224

24. S.G. Bolder, H. Hendrickx, L.M.C. Sagis, E. van der Linden, J Agric. Food Chem. 54(12), 4229-4234 (2006). doi:10.1021/ jf060606s

25. C. Akkermans, P. Venema, S.S. Rogers, A.J. van der Goot, R.M. Boom, E. van der Linden, Food Biophys. 1, 144-150 (2006). doi:10.1007/s11483-006-9012-5

26. F. Chiti, C.M. Dobson, Annu. Rev. Biochem. 75, 333-366 (2006) doi:10.1146/annurev.biochem.75.101304.123901

27. C.M. Dobson, Nature. 426(6968), 884 (2003). doi:10.1038/ nature 02261

28. G.G. Glenner, N. Engl. J. Med. 302, 1383-1292 (1980)

29. G.G. Glenner, N. Engl. J. Med. 302, 1333-1343 (1980)

30. L.C. Serpell, M. Sunde, C.C.F. Blake, Cell. Mol. Life Sci. 53, 871-887 (1997). doi:10.1007/s000180050107

31. R. Nelson, M.R. Sawaya, M. Balbirnie et al., Nature. 435, 773 778 (2005). doi:10.1038/nature03680

32. G.G. Glenner, D.L. Page, E.D. Eanes, J. Histochem. Cytochem. 20(10), 821-826 (1972)

33. H.H. Naiki, Anal. Biochem. 177(2), 244 (1989). doi:10.1016/ 0003-2697(89)90046-8

34. E.H.C. Bromley, M.R.H. Krebs, A.M. Donald, Faraday Discuss. 128, 13-27 (2005). doi:10.1039/b403014a

35. W.S. Gosal, A.H. Clark, S.B. Ross-Murphy, Biomacromolecules. 5(6), 2408-2419 (2004). doi:10.1021/bm049659d

36. H. LeVine, Methods Enzymol. 309, 285-305 (1999). doi:10.1016/ S0076-6879(99)09021-7

37. H. Naiki, F. Gejyo, Methods Enzymol. 309, 305-318 (1999). doi:10.1016/S0076-6879(99)09022-9

38. L. Nielsen, R. Khurana, A. Coats et al., Biochemistry. 40(20), 6036-6046 (2001). doi:10.1021/bi002555c

39. M. Groenning, L. Olsen, M. van de Weert, J.M. Flink, S. Frokjaer, F.S. Jørgensen, J. Struct. Biol. 158, 358-369 (2007). doi:10.1016/j.jsb.2006.12.010

40. J. Israelachvili, Intermolecular \& Surface Forces (Academic, California, USA, 1992), pp. 341-365

41. S.S. Rogers, Some physical properties of amyloid fibrils, $\mathrm{PhD}$ Thesis, Cambridge University, UK, 2005.

42. E.K. Hill, B. Krebs, D.G. Goodall, G.J. Howlett, D.E. Dunstan, Biomacromolecules. 7(1), 10-13 (2006). doi:10.1021/bm0505078

43. S.G. Bolder, L.M.C. Sagis, P. Venema, E. van der Linden, J. Agric. Food Chem. 55(14), 5661-5669 (2007). doi:10.1021/ jf063351r

44. F. Meersman, C.M. Dobson, Biochim. Biophys. Acta (BBA)Proteins \& Proteomics 1764(3), 452-460 (2006)

45. J.-A. Yu, S.-H. Oh, Y-R. Park, J.-S. Kim, Macromol. Symp. 249250, 445-449 (2007). doi:10.1002/masy.200750417 